\title{
A Case Study of Teacher's Politeness in EFL Class
}

\author{
Xiaoqing Jiang \\ School of Foreign Languages, Qingdao University of Science and Technology, Qingdao, Shandong, China \\ Email: qdjxq@sina.com
}

\begin{abstract}
Politeness is an important factor in human interaction. In the past two decades or so, much has been written and different theories have emerged about politeness. This is a case study of a Chinese EFL teacher's linguistic politeness in classroom based on observation, recorded data and interview with both the teacher and the students. Then a conclusion is drawn that politeness does exist in EFL classroom and it does contribute to both teaching and learning.
\end{abstract}

Index Terms - politeness, politeness principle, politeness strategy, speech acts

\section{INTRODUCTION}

Politeness appears to be a prevalent concept and an important factor in human interaction. As regards its definition, it is often considered socioculturally appropriate behavior and is characterized as a matter of abiding by the expectations of society. According to Routledge Dictionary of Language and Linguistics, politeness is a term for a combination of interpersonal considerations and linguistic choices affecting the form and function of linguistic interactions. In different cultures and different contexts, politeness refers to quite different things. This study focuses on the teachers' politeness in an EFL class, in which both the teacher and learners are Chinese with Chinese culture. Politeness can be expressed verbally and non-verbally, but in this study, only linguistic politeness is discussed; that is, the ways the teacher expresses politeness verbally through her use of language. To do the research, an EFL class (two periods, i.e. two hours), an intensive reading class of non-English majors in a university is observed and recorded, and then an interview with the students helps to confirm the findings.

\section{RELATED THEORIES}

In the past two decades or so, much has been written and different theories have emerged about "politeness". In this paper, Leech's politeness principle, Brown and levinson's face theory and politeness strategy, Austin and Searle's speech act theory are mainly employed in analyzing the teacher's politeness this English class.

\section{A. Politeness Principle}

In "Principle of Pragmatics"(1983a), British linguist Geoffrey N. Leech explains the important function of politeness to linguistic communication and regards politeness principal and cooperative principal proposed by $\mathrm{H}$. $\mathrm{P}$. Grice as the two basic principles on which communication should be based. Leech first introduces the Politeness Principle as a necessary supplement for Grice's Cooperative Principle. He regards what he calls the "politeness principle" as one of the fundamental pragmatic principles that one usually observes when one communicates in language. He proposed six maxims of the politeness principle: the tact maxim(The speaker minimizes the cost and correspondingly maximizes the benefit to the listener), the generosity maxim(The speaker minimizes the benef it and correspondingly maximizes the cost to self), the approbation maxim(The speaker minimizes dispraise and correspondingly maximizes praise of the listener), the modesty maxim(The speaker minimizes praise and correspondingly maximizes dispraise of self), the agreement maxim(The speaker minimizes disagreement and correspondingly maximizes agreement between himself and the listener), and the sympathy maxim(The speaker minimizes antipathy and correspondingly maximizes sympathy between himself and the listener).

\section{B. Face Theory and Politeness Strategy}

P. Brown and S. levinson's work "Universals in Language Usage: Politeness Phenomena" (1978) gives a very detailed analysis of politeness phenomena and proposes a universal theory of cross-cultural politeness phenomena whose core concept is "face". According to Brown and Levinson, politeness strategies are developed in order to save the hearers' "face". Face refers to the respect that an individual has for him or herself, and is for maintaining that "self-esteem" in public or in private situations. An individual's face consists of two desires: the desire to be approved of by others (termed "positive face") and the desire to be unimpeded by others in one's actions (termed "negative face"). Either or both of them can be threatened by certain FTAs such as ordering, advising, or offering. Face Threatening Acts (FTA's) are acts that infringe on the hearers' need to maintain his/her self-esteem, and to be 
respected. Politeness strategies are developed for the main purpose of dealing with these FTA's. There are four types of politeness strategies, described by Brown and Levinson, that sum up human "politeness" behavior: Bald On Record, Positive Politeness, Negative Politeness, and Off-Record.

\section{Speech Act Theory}

Speech act theory is built on the foundation laid by Wittgenstein and Austin. John Searle is most often associated with the theory. Ludwig Wittgenstein thinks that the meaning of language depends on its actual use. According to Austin, to say something is to do something. In other words, saying is an act of utterance. His lecture series entitled "How to Do Things with Words"(1962) implies that we do things, not only say things, with words. Austin points out that there are at least three components in a speech act: Locutionary act, Illocutionary act, and Perlocutionary act. According to Searle, to understand language one must understand the speaker's intention. Since language is intentional behavior, it should be treated like a form of action. Thus Searle refers to statements as speech acts. The speech act is the basic unit of language used to express meaning, an utterance that expresses an intention. When one speaks, one performs an act. Searle, while allowing that there is a myriad of language particular speech acts, proposed that all acts fall into five main types: representatives, directives, commissives, expressives, and declarations.

With six years' teaching experiences, I find teachers have the following roles in class: instructional, motivational, evaluative, and managerial. All classroom speech acts can be categorized according to these functions. Traditionally, the teacher controls learning and behavior in the classroom with these kinds of speech acts. So here I refer to these acts as control speech acts of the teacher. This paper is about which politeness strategies and how they are employed in teachers' control speech acts in EFL classrooms. Then an analysis will be made as to how much percent each strategy makes up and why it is so.

\section{FINDINGS OF THE STUDY}

I transcribed the record to get the detailed data of the polite language that the teacher uses. In this study, any language that is to enhance the process of teaching and to benefit the interaction between teacher and students is classified as politeness. In the following part, the teacher's politeness will be analyzed from the angles of the different classroom control speech acts mentioned above. Then tables will be given to show the distribution of different strategies, thereby studying the teacher's politeness in this English class.

\section{A. Academic Instructions}

This refers to the teacher's academic presentation, answering students' academic questions, and supportive and corrective feedback. Look at the following sentences:

1) Let's begin today's class.

2) We will learn a moving story today, it's about a widow.

3) I'd like you to read the new words after me, please.

4) So much for the new words, stop here, please.

5) Please find a word which means "satisfactory".

6) Please tell me what the author tell us in paragraph two.

7) Shall we go on?

8) Who would like to come to the blackboard?

9) Can you show me the difference between the two words?

10) Turn to page 115 , look at the first line.

11) Next time, we will study unit 9 , preview it and hand in your homework as soon as possible.

These are the very sentences that are frequently used in teaching a new lesson. Every English teacher won't feel unfamiliar with them. In these sentences, a number of politeness strategies are employed. The following is the analysis:

The first two sentences show a positive politeness strategy. Within in Brown and levinson's theory, when you speak to someone, you may orient yourself towards that individual's positive face, and employ positive politeness, which appeals to the hearer's desire to be liked and approved of. Here, one of the positive strategies - in-group marker is used, that is, the teacher includes herself in the learning process, which will shorten the distance from the students.

Sentences 3-6 appear in the form of imperative sentences. This is a direct strategy of politeness. In such kind of strategy, the illocutionary act is expressed clearly through language forms. In forms, imperative sentences are often used, or other similar sentences like perfomatives $(\mathrm{S} 4,5)$, obligation statement(S6), want statement(S3), etc. And this can also be classified as one of the negative politeness strategies.

Sentences7-9 show another of the negative politeness strategies-conventionally indirectness. Negative politeness is oriented towards a hearer's negative face, which appeals to the hearer's desire not to be impeded or put upon, to be left free to act as they choose. In classroom, module verbs such as shall, would, can, etc are often used to maintain the students' negative face. 
Sentence 10 and 11 appear to be very common sentences, but actually they show another politeness strategy-bold on record. This type of strategy is commonly found with people who know each other very well, and are very comfortable in their environment, such as close friends and family. There are also occasions when external factors constrain a person to speak very directly, for example, there is an emergency of some sort, or where there is a major time constraint or where there is some form of channel limitation. Under such circumstances, the speaker is likely to focus on the propositional content of the message, and pay little attention to the interpersonal aspect of what is said. This strategy is employed often in the teaching process in the classroom. On one hand, teachers usually try to establish a harmonious relationship with the students, try to be "close" to students; on the other hand, time is limited in class, teachers have to finish the teaching task in prearranged time, and, especially before the class is over, students are eager to go and time for teachers to assign homework is limited, so this strategy is often employed in these circumstances. In this classroom, things are just the same.

\section{B. Motivation}

Motivation refers to various illocutionary acts aimed at activating students such as their participation, academic questions, and initiative feedback. The following are the Examples:

12) Hey, guys, what are you doing? Why are you so sleepy?

13) Wang Qun, you give us a presentation, ok?

14) Chen Shuo, tell us the story "The yellow ribbon around the old oak tree", all right?

15) Just say it in your own words, I know you can, have a try, will you?

16) It's quite necessary to request English learners to speak English. Don't keep silent!

17) It's not a good habit to memorize the new words from the word list. Get help from the text!

Sentence 12 is an expression of positive politeness. Because the teacher here is trying to minimize the distance between herself and the students by expressing friendliness(Hey, guys) and solid interest in the hearer's need to be respected (minimize the FTA). (Ask the students what they are doing, why they are so sleepy instead of scolding them for their distraction and their sleepiness)

In sentences 13-15, “ok", "all right", "will you" are used. Such words are called "filler", one of the strategy of mitigation according to Fraser, who holds that politeness is closely related to mitigation, and it can be said that only when the speaker is polite, mitigation exists. This can also be a kind of positive politeness strategy which finds close parallel in Leech's politeness principles: seek agreement, avoid disagreement (agreement principle), maximize praise of the listener (approbation principle) and give sympathy (sympathy principle).

Sentences 16 and 17 contain the bald-on record strategy mentioned above as in "Don't keep silent", "Get help from the text". The other strategy employed in them is one of the negative politeness strategies - impersonalize speaker and hearer. Here, no specific student is mentioned, the teacher is activating all the students by maintaining the students' negative face-don't impede them.

\section{Evaluation}

Evaluation is indispensable in English class. It refers to teacher's positive and negative feedback which is very important to students. It can encourage as well as discourage the students. Therefore, politeness in evaluation is particularly important to both learning and teaching.

18) Good! You are right!

19) Exactly!

20) Well done!

21) Perfect! Sit down please!

22) You are using a big word here. (hint to change a word)

23) How many Zhang Xiang do we have here? (hint to the other students not to speak)

24) She tell her husband? (hint at a grammar mistake)

25) I am afraid the focus of this article may be the love between the widow and her dead husband..

26) Well, I agree with you to a certain point. However...

27) Perhaps you can use another way to express yourself.

28) Maybe first you should read the directions carefully.

29) I am sorry, I mean translate this sentence into Chinese.

30) Maybe it's my fault, I didn't emphasize that in the previous class.

Sentences 18-21 are praises often generously given by the teacher. It's easily seen that in saying this the teacher is employing the positive politeness strategy, the approbation principle, agreement principle and sympathy principle to maintain the students' positive face.

Another politeness strategy is employed in sentences22-26: off-record, a kind of indirect politeness strategy. In this strategy, the speaker is removing himself from any imposition whatsoever. Usually, giving hints, using metaphor, being ambiguous or vague, using ellipsis are ways to carry out this strategy. In Senteces $22-24$, the teacher is not criticizing the student directly; instead, she uses the indirect way to hint at the mistake or the improper performance of the students, thus maintaining their face. While in Sentences25-26, the teacher is being ambiguous by using "I'm afraid", "Well”, "to a certain point" to show indirectly that there's something w rong with 
the student's answers. And here, the tact principle and agreement principle is reflected.

"Perhaps", "maybe" in sentences 27 and 28 are markers of another negative politeness principle-hedge. The teacher maintains the student's negative face by using these words. The similar expressions are: I think, I hope, I suggest, etc. Of course, the strategy of hint is also reflected in them, which is often the case in many other examples: not only one strategy is employed. Here, the tact principle and sympathy principle are applied.

In sentences 29 and 30, one of the negative politeness strategies - admit the impingement is employed. The teacher here is trying to admit her own fault in order to save the student's negative face. Besides, the tact principle, generosity principle, and modest principle are used here.

\section{Classroom Management}

This refers to discipline instructions, discipline directives (orders, requests, questions, and calls), procedural instructions, and procedural directives.

31) Be quite, please!

32) Stop talking, please!

33) Now talk with your partner about this problem.

34) Divide into groups, please.

35) Why don't you sit closer?

36) I'd be grateful if you answer this questionnaire for me.

37) Be quick, you have only five minutes.

38) Please stop here; we don't have enough time for you to remember all these new words in class.

In sentence 31 and 32 , the teacher is using the bald-on-record strategy by ordering the students directly to maintain classroom order in the shortest possible time.

In sentences 33-35, the direct strategy is used once again. Sentences33 and 34 appear in imperative sentences and Sentence 35 use an interrogative sentence.

Sentence 36 reflects a negative politeness strategy: go on record as incurring a debt. In assigning this task, the teacher is using this strategy to be polite for this is a kind of help from the students.

In sentences 37 and 38, several politeness strategies are used together. First, imperative sentences of the direct politeness are used; then, one of the positive politeness strategies - in group identity marker is used; next, a kind of mitigation strategy is also used: supportive moves. "You have only five minutes", "we don't have enough time for you to remember all these new words in class" can be looked on as the supportive moves here which present the reasons for the central moves. The purpose of teacher's using this is to get the students' understanding and cooperation.

\section{ANALYSIS AND DISCUSSION}

The study can be clearly shown in the following two tables (As for those sentences which employ more than one strategies, only one major strategy is counted in the table.):

\begin{tabular}{|c|c|c|c|c|c|}
\hline \multicolumn{1}{|c|}{ TABLE 1} & Off-record & total \\
\hline strategy & Bald-on-record & positive & negative & 10 & 71 \\
\hline number & 15 & 26 & 20 & $14.1 \%$ & $100 \%$ \\
\hline percentage & $21.1 \%$ & $36.6 \%$ & $28.2 \%$ & $1 \%$ & \\
\hline
\end{tabular}

TABLE 2

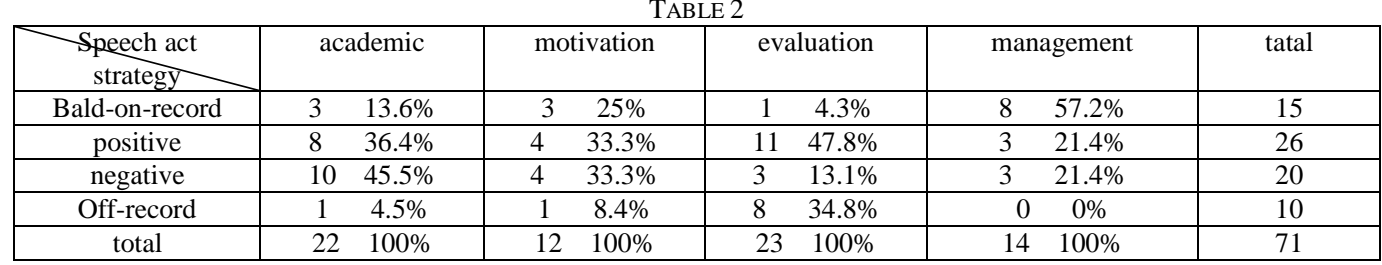

\section{A. Table 1}

In the process of this English class, I altogether got 71 of teacher's sentences that have something to do with politeness. From Table1, it can be easily seen that in this English class, the teacher employs all the four strategies, with the positive strategy making up the greatest proportion: $36 \%$, and next negative strategy $28.2 \%$, then bald bald-on-record strategy $21 \%$ and lastly off-record only $14.1 \%$. The numbers show that the teacher is quite concerned with the students' need to be liked or approved of, and she is trying not to hinder or obstruct the students' thought as well as their activities. That the off-record instead of bald-on-record is the least used strategy is a little bit surprising. I had thought the bald-on-the record would be the least because this strategy is often used between friends or people who know each other well. In this class, the teacher is a young girl and she has quite harmonious relationship with the students. This can be easily seen through my interview with her and her students. So this is one reason why the bald-on-record strategy is used in her class more than I had thought. The second 
reason may be that the time when I did the research is near the end of the term. The teacher is hurrying to finish the prearranged teaching task, so off-record strategy such as hint, vagueness, metaphor, etc is used less while bald-on-record which is direct is used more.

\section{B. Table 2}

I also found it was interesting to analyze the distribution of the different strategies in the different speech acts. From Table2, we can see in academic instruction, negative strategy occupies the most part: $45.5 \%$. This shows that in teaching, the teacher is trying to give the students the most possible freedom to act as they choose in class. She doesn't want to impede them by her acts. Positive strategy occupies $36.4 \%$ in this speech act, which means the teacher is trying to take the student's desire to be liked or approved of into full consideration in her teaching process. Off-record is used the least in this speech act because the teaching method in this class can hardly be called "student-centered", so it is the teacher who speaks the most in class. She needn't use much hint or metaphor in carrying out her teaching.

As for the motivation act, positive and negative strategies have equal proportion and are the most employed strategies in this speech act. As is mentioned above, in activating the student, the teacher is also taking into account the students' desire to be approved and need to be unimpeded. Like in the academic instruction act, off-record strategy is used the least here because time is limited and the close relationship allows more bald-on-record strategy.

In the evaluation act, positive strategy still occupies the most proportion: 43\%. This tells us the teacher is making great efforts to encourage the students: giving the most possible approval and agreement, which will contribute to the students' interested learning and active participation. Here, bald-on-record is used the least, because the teacher doesn't want to embarrass the students by her comment. So this strategy is only used occasionally with a proportion of $4.3 \%$, while off-record strategy is more frequently used for the teacher is trying to point out the students' mistakes or shortcomings indirectly.

Contrary to this, in the management act, bald-on-record is used most with the proportion of $57.2 \%$. The teacher doesn't want to spend much time in managing the class, so she uses the direct way to maintain the discipline and give procedure orders. In this act, positive and negative strategy again makes up the same proportion: $21.4 \%$ while no off-record is found maybe because there is no need to be so indirect in managing a class.

\section{CONCLUSION}

From the analysis above, also from my observation and interview with the teacher and the students, a conclusion can be drawn that politeness does exist in this EFL class; politeness does promote the mutual understanding and harmonious relationship between teacher and students; politeness does enhance teaching and benefit the students; politeness does contribute to the effective interaction and friendly, lively atmosphere in EFL classroom.

\section{REFERENCES}

[1] Leech G N. (1983). Principles of pragmatics. Longman, London.

[2] P.Brown and S.levinson. (1978). Universals in Language Usage: Politeness Phenomena. Cambridge University Press, Cambridge.

[3] Austin J L. (1962). How to do things with words. Oxford University Press, Oxford.

[4] Jenny Thomas. (1995). Meaning in interaction: an introduction to pragmatics. Longman Publishing, New York.

[5] Hadumod Bussmann. (2000). Routledge Dictionary of Language and Linguistics. Foreign Language Teaching and Research Press.

[6] Dexing Wang. (1998). English Discourse Analysis and Intercultural Communication. Beijing Language and Culture University Press.

Xiaoqing Jiang was born in Qingdao, China in 1976. She received her M.A. degree in linguistics from Ocean University of China in 2005.

She is currently a lecturer in the college of foreign languages, Qingdao University of Science and Technology, Qingdao, China. Her research interests include applied linguistics and English language teaching. 